\title{
Growth and physiology of a dominant understory shrub, Hamamelis virginiana, following canopy disturbance in a temperate hardwood forest
}

\begin{tabular}{|c|c|}
\hline Journal: & Canadian Journal of Forest Research \\
\hline Manuscript ID & cjfr-2016-0208.R3 \\
\hline Manuscript Type: & Article \\
\hline Date Submitted by the Author: & 08-Sep-2016 \\
\hline Complete List of Authors: & $\begin{array}{l}\text { Taylor, Benton; Columbia University, Ecology, Evolution, and } \\
\text { Environmental Biology } \\
\text { Patterson, Angelica; Columbia University, Department of Earth and } \\
\text { Environmental Sciences } \\
\text { Ajayi, Moyosore; Vanderbilt University, Department of Earth and } \\
\text { Environmental Sciences } \\
\text { Arkebauer, Rachel; Columbia University, Ecology, Evolution, and } \\
\text { Environmental Biology } \\
\text { Bao, Karen; Columbia University, Ecology, Evolution, and Environmental } \\
\text { Biology } \\
\text { Bray, Natalie; Cornell University, Department of Entomology } \\
\text { Elliott, Robert; Columbia University, Earth Institute } \\
\text { Gauthier, Paul; Princeton University, Department of Geosciences } \\
\text { Gersony, Jessica; Harvard University, Organismic and Evolutionary Biology } \\
\text { Gibson, Rebecca; Columbia University, Ecology, Evolution, and } \\
\text { Environmental Biology } \\
\text { Guerin, Marceau; Columbia University, Department of Earth and } \\
\text { Environmental Engineering } \\
\text { Lavenhar, Sara; Columbia University, Ecology, Evolution, and } \\
\text { Environmental Biology } \\
\text { Leland, Caroline; Columbia University, Department of Earth and } \\
\text { Environmental Sciences } \\
\text { Lemordant, Leo; Columbia University, Department of Earth and } \\
\text { Environmental Engineering } \\
\text { Liao, Wenying; Princeton University, Department of Ecology and } \\
\text { Evolutionary Biology; Columbia University, Ecology, Evolution, and } \\
\text { Environmental Biology } \\
\text { Melillo, Jerry; Marine Biological Laboratory, The Ecosystems Center } \\
\text { Oliver, Ruth; Columbia University, Department of Earth and Environmental } \\
\text { Sciences } \\
\text { Prager, Case; Columbia University, Ecology, Evolution, and Environmental } \\
\text { Biology } \\
\text { Schuster, William; Black Rock Forest Consortium } \\
\text { Schwartz, Naomi; Columbia University, Ecology, Evolution, and } \\
\text { Environmental Biology } \\
\text { Shen, Christa; Columbia University, Ecology, Evolution, and Environmental }\end{array}$ \\
\hline
\end{tabular}




\begin{tabular}{|l|l|}
\hline & $\begin{array}{l}\text { Biology } \\
\text { Terlizzi, Katherine; Black Rock Forest Consortium } \\
\text { Griffin, Kevin; Columbia University, Ecology, Evolution, and Environmental } \\
\text { Biology; Columbia University, Department of Earth and Environmental } \\
\text { Sciences }\end{array}$ \\
\hline Keyword: & $\begin{array}{l}\text { Black Rock Forest, canopy disturbance, foliar chemistry, photosynthesis, } \\
\text { respiration }\end{array}$ \\
\hline
\end{tabular}

\section{SCHOLARONE \\ Manuscripts}


1 Growth and physiology of a dominant understory shrub, Hamamelis

2 virginiana, following canopy disturbance in a temperate hardwood forest

BENTON N. TAYLOR*¹, ANGELICA E. PATTERSON ${ }^{2}$, MOYOSORE AJAYI ${ }^{3}$, RACHEL

4 ARKEBAUER ${ }^{1}$, KAREN BAO $^{1}$, NATALIE BRAY ${ }^{1}$, ROBERT M. ELLIOTT ${ }^{4}$, PAUL P.G.

5 GAUTHIER ${ }^{5}$, JESSICA GERSONY ${ }^{6}$, REBECCA GIBSON ${ }^{1}$, MARCEAU GUERIN $^{7}$, SARA

6 LAVENHAR $^{1}$, CAROLINE LELAND $^{2}$, LÉO LEMORDANT $^{7}$, WENYING LIAO ${ }^{1,8}$, JERRY $^{2}$

7 MELILLO $^{9}$, RUTH OLIVER $^{2}$, CASE M. PRAGER $^{1}$, WILLIAM SCHUSTER ${ }^{10}$, NAOMI

8 SCHWARTZ $^{1}$, CHRISTA SHEN $^{1}$, KATHERINE PAVLIS TERLIZZI $^{10}$, KEVIN L. GRIFFIN $^{1,2}$

9 RRH: ECOPHYSIOLOGY RESPONSES OF WITCH-HAZEL TO CANOPY

DISTURBANCE

11 Author Affiliations: ${ }^{1}$ Columbia University, Ecology Evolution and Environmental Biology

12 Department, $10^{\text {th }}$ Fl Schermerhorn Extension, 1200 Amsterdam Ave. New York, NY 10027

$13{ }^{2}$ Columbia University, Department of Earth and Environmental Sciences, $5^{\text {th }}$ Fl Schermerhorn

14 Extension, 1200 Amsterdam Ave. New York, NY 10027

$15{ }^{3}$ Vanderbilt University, Department of Earth and Environmental Sciences, 5726 Stevenson

16 Center, Nashville, TN 37240

$17{ }^{4}$ Columbia University, Civil Engineering and Engineering Mechanics, $500 \mathrm{~W}$ 120th St., New

18 York, NY 10027

$19{ }^{5}$ Princeton University, Department of Geosciences, Guyot Hall, Princeton, NJ 08544

$20{ }^{6}$ Harvard University, Department of Organismic and Evolutionary Biology, 26 Oxford St.,

21 Cambridge, MA 02138 
$22{ }^{7}$ Columbia University, Department of Earth and Environmental Engineering, 500 W. $120^{\text {th }}$ St., 23918 S.W. Mudd Hall, 500, New York, NY 10027

$24{ }^{8}$ Princeton University, Department of Ecology and Evolutionary Biology, Guyot Hall, Princeton, $25 \quad$ NJ 08544

$26{ }^{9}$ Marine Biological Laboratory, The Ecosystems Center, 7 MBL St., Woods Hole, MA 02543

$27{ }^{10}$ Black Rock Forest Consortium, 65 Reservoir Road, Cornwall, NY 12518

$28 *$ Corresponding Author: bentonneiltaylor@gmail.com; (865) 919-5925 


\section{Abstract}

As global climatic changes increase plant susceptibility to large-scale disturbances like

31 drought and pathogens, understory responses to these disturbances will become increasingly

32 important to long-term forest dynamics. To better understand understory responses to canopy

33 disturbance, we measured changes in the growth and physiology of the dominant understory

34 shrub, American witch-hazel (Hamamelis virginiana), in response to girdling of canopy oaks in a

35 northeastern U.S. temperate hardwood forest. Changes in the growth and physiology of $H$.

36 virginiana may be important to the regeneration of northeastern temperate forests, as this

37 common shrub largely shapes the microenvironment for seedlings on the forest floor where it

38 occurs. Canopy disturbance by girdling resulted in significant increases in light and soil nitrogen

39 availability. In response to these environmental changes, basal-area growth of $H$. virginiana

40 increased by an average 334\%. This growth increase corresponded to significant increases in

41 foliar nitrogen, respiration, and leaf chlorophyll and carotenoid concentrations. These findings

42 indicate improved environmental conditions and increased growth for this understory shrub

43 following the loss of dominant canopy trees. This study suggests that following large-scale

44 canopy disturbance, $H$. virginiana and shrubs like it may play an important role in competing for

45 soil $\mathrm{N}$ and shading seedlings of regenerating canopy species.

46 Keywords: Black Rock Forest, canopy disturbance, foliar chemistry, photosynthesis, respiration 
47 58 forests.

\section{Introduction}

Temperate hardwood forests play an important role in the regulation of water and nutrients, sequestration of carbon (C), and providing habitat for biodiversity. In the U.S. and southern Canada, many temperate forests are dominated by oaks (Quercus spp.), where “oakhickory" is the largest single forest type, covering 139 million acres and comprising almost one fifth of all U.S. forested land (US Forest Service 2007). Oaks currently face large-scale mortality from pathogens and regeneration failure (Lorimer 1993, Shifley et al. 2006, Fan et al. 2008), similar to the die-offs of American chestnut (Castanea dentata (Marsh.) Borkh.) and Eastern Hemlock (Tsuga canadensis (L.) Carrière) during the $20^{\text {th }}$ century. Understanding the effects of such large-scale mortality from pathogens, and the recolonization process following the loss of canopy oaks, is important for predicting the stability and function of future temperate hardwood

North American oaks are currently at risk due to a wide variety of pathogenic threats. These pathogens include oak wilt (Juzwik et al. 2008), leaf scorch bacteria (Barnard 2007, McElrone et al. 2008), Armillaria root fungus (Marçais and Bréda 2006, Fan et al. 2008, Kabrick et al. 2008), and red oak borer (Shifley et al. 2006, Fan et al. 2008, Kabrick et al. 2008) - all of which are established in eastern hardwood forests. Additionally, the sudden oak death pathogen (Rizzo et al. 2002) has resulted in large-scale oak mortality in the western U.S. (Meentemeyer et al. 2008), and the susceptibility of eastern oak species to this water mold presents a major potential threat to the vast oak forests of eastern North America (Tooley and Kyde 2003, 2007). In eastern temperate forests, competition from other shade-tolerant species (Lorimer 1993, Parker and Dey 2008), intense herbivory (predominantly by white-tailed deer (Rooney and Waller 2003)), and altered fire regimes (Kruger and Reich 1997) may all contribute to 
suppressing the regeneration of oak seedlings, potentially amplifying the effects of these pathogens. The transition away from canopies dominated by oak species following human and natural disturbance has been well documented throughout eastern North America (Lorimer 1993, Kruger and Reich 1997). Thus, predicting which tree species will replace canopy oaks following large-scale pathogen mortality, and what environmental factors govern this replacement process, is key to understanding future functioning of northeastern temperate forests.

A primary competitor of canopy species' seedlings in many temperate North American forests is American witch-hazel (Hamamelis virginiana L.; Gleason and Cronquist 1963). This woody shrub takes up soil resources and casts shade, largely driving understory environmental conditions where it is common. Strong secondary compounds in the tissue of $H$. virginiana deter herbivory of this species (Duckstein and Stintzing 2011), allowing it to become especially dominant in forests where herbivores strongly influence understory ecology (as is the case throughout much of the eastern temperate U.S.; Rooney 2001). Because of the large potential impact that shrubs such as $H$. virginiana can have on the growth of seedlings below their crown (Lorimer et al. 1994), responses of this species to canopy oak loss may be particularly important in determining which species replace canopy oaks.

Forest canopies largely shape the environmental conditions of the forest floor. Loss of dominant canopy trees can dramatically alter light and soil resource availability in the understory (Parker and Dey 2008), making the physiological responses of $H$. virginiana to these novel conditions important to its success in changing forests. Previous studies have shown dramatic increases in light and soil ammonium $\left(\mathrm{NH}_{4}\right)$ availability following experimentally induced mortality of canopy dominants (Jenkins et al. 1999, Lustenhouwer et al. 2012). Additional changes to water, phosphorus, soil organic matter, and microbial pools might also be expected as 
93 large components of the forest canopy turnover. For H. virginiana, similar environmental

94 changes have been shown to alter growth (Hicks and Hustin 1989), leaf anatomy (Abrams and 95 Kubiske 1990), and internal nutrient dynamics (Boerner 1985).

We designed this study to increase our understanding of the physiological responses of $H$.

97 virginiana to canopy oak loss and to identify potential ecological consequences of these responses for temperate hardwood forests. To do this, we measured changes in several

99 environmental and physiological variables 5 years after girdling of the dominant canopy oaks in 100 a temperate Northeastern U.S. forest. Specifically, we aimed to document responses of growth, 101 foliar nitrogen $(\mathrm{N})$ and carbon (C), leaf pigments, photosynthesis, and foliar respiration of $H$. 102 virginiana to canopy disturbance. We hypothesized that large-scale canopy disturbance would 103 increase light and soil $\mathrm{N}$ availability, increasing both the supply-to and demand-of $\mathrm{N}$ by the 104 leaves of $H$. virginiana. We predicted that higher foliar $\mathrm{N}$ concentrations would increase 105 photosynthesis and respiration rates, which would lead to increased growth of this important 106 understory species.

107 Methods

108 Study Site

This study, part of the Future of Oak Forests experiment, was located on the north slope of Black Rock Mountain $\left(41.45^{\circ} \mathrm{N}, 74.01^{\circ} \mathrm{W}\right)$ at the Black Rock Forest (BRF) Consortium in 111 the Hudson Highlands region of southeastern New York. As a temperate forest, BRF has an 112 annual precipitation of approximately $1200 \mathrm{~mm}$ and a mean annual air temperature of $9.7^{\circ} \mathrm{C}$.

113 Temperatures at this site show strong seasonal variation, with mean monthly temperatures 114 ranging from $-2.7^{\circ} \mathrm{C}$ to $23.4^{\circ} \mathrm{C}$ (NOAA 2002). Red oak (Quercus rubra, L.) and chestnut oak 
115 (Quercus montana, Willd.) are the most widely distributed and common canopy trees, with oaks 116 comprising approximately $67 \%$ of the hardwood basal area at BRF (Schuster et al. 2008). The

117 understory tree community is dominated by red maple (Acer rubrum, L.), black gum (Nyssa

118 sylvatica, Marsh.), black birch (Betula lenta, L.) and sugar maple (Acer saccharum, Marsh.)

119 (Schuster et al. 2008, Levy-Varon et al. 2012, 2014). H. virginiana is, by far, the most common

120 understory shrub species $>100 \mathrm{~cm}$ height at this experimental site (adult densities $=566$

121 individuals $\mathrm{ha}^{-1}$ ).

122

Experimental Design and Sampling Scheme

The Future of Oak Forests experiment at BRF was implemented in 2008 with the goal of

124 understanding changes in stand-level nutrient cycling and regeneration responses following

125 dominant canopy tree loss. This experiment comprises four treatments replicated in three blocks:

$126100 \%$ oaks girdled, 50\% oaks girdled, 100\% non-oaks girdled, and control plots where no

127 girdling occurred (labelled “O”, “O50”, "N”, and "C" respectively, Figure 1). Girdling was

128 performed on trees $>2.54 \mathrm{~cm} \mathrm{DBH}$ according to the notch girdling technique described by Noel

129 (1970), using a chain saw to sever phloem transport of carbon between leaves and roots causing 130 gradual mortality of the tree to simulate natural death from pathogen attack. Understory oaks $<$

$1312.54 \mathrm{~cm} \mathrm{DBH}$ in the $100 \%$ girdled plots were felled completely as their bark tissue was too thin

132 to reliably girdle. Mortality of girdled trees occurred 1-3 years following girdling

133 implementation. There was no removal of leaf litter or woody debris in any plot at any point

134 during the experiment. Girdling treatments are arranged in a complete randomized block design

135 with blocks corresponding to slope position. Here, we sampled the control and 100\% oak

136 girdled treatments - 6 plots distributed across the 3 experimental blocks (plots A3, A4, B2, B4,

$137 \mathrm{C} 1$, and $\mathrm{C} 2$, highlighted in Figure 1). 
Each experimental plot is divided into 9 equal $25 \mathrm{~m}$ x $25 \mathrm{~m}$ subplots. Within the central

139

140

141

142

143

144

145

146

147

148

149

150

151

152

153

154

155

156

157

158

159

160

subplot of each plot, three adult $H$. virginiana individuals were selected, one closest to each of

the northeast corner, center, and southwest corner of the subplot. This sampling scheme resulted in measurements taken on 9 individuals in each of the 2 experimental treatments. All physiological measurements of $H$. virginiana were taken on October 5 and 6, $2013-$ approximately 5 years following the application of the girdling treatment. Sampling was conducted on leaves normally receiving direct sunlight and prior to any visible signs of fall leaf senescence for $H$. virginiana at this site. Data for photosynthetic rates and respiratory capacity were obtained from lab measurements of detached $H$. virginiana branches from each study plot. Measurements conducted in the lab utilized branches from the outer crown, harvested from each individual before dawn, and transported to the lab with their proximal end submerged in water to preserve tissue water potential. Branches were kept outdoors in direct sunlight until measurements were taken, and all lab measurements were conducted the same day that branches were harvested. We stress that our intent was to compare photosynthetic and respiratory capacities, not in situ rates. All detached branches were treated similarly and no loss of photosynthetic or respiratory capacity has been observed between attached and detached branches of woody plants (A.E. Patterson, unpublished data). Although lab and field measurements were taken on the same set of 18 plants, the individual leaves used for lab and field measurements were different.

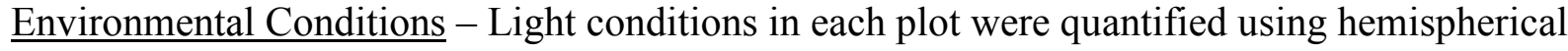
photographs of the canopy of each plot over a 3-year period from 2009-2012. Hemispherical photographs of the canopy were taken using a fisheye lens $1 \mathrm{~m}$ above the ground at each of the four corners of each experimental plot during the summer of each year. Photographs were 
161 analyzed using Gap Light Analyzer software (Cary Institute for Ecosystem Studies, NY, USA).

162 Mean daily air temperature in each plot was measured from the summer of 2008 through the end 163 of 2012 using 107-T temperature sensors (Campbell Scientific Inc., UT, USA) installed within 164 radiation shelters at the center of each plot approximately $2 \mathrm{~m}$ above the ground.

Concentrations of soil ammonium $\left(\mathrm{NH}_{4}\right)$ and nitrate $\left(\mathrm{NO}_{3}\right)$ were determined from both 166 organic- and mineral-layer soil samples collected every two-three months through the growing

167 season from October 2007 - June 2011. These concentrations were considered to be indicators of 168 nitrogen availability to the vegetation. Soil samples were taken with a $7.62 \mathrm{~cm}$ diameter soil core 169 to a depth of $15.25 \mathrm{~cm}$, separated into organic and mineral layers in the field, sieved, and 170 extracted in $2 \mathrm{M} \mathrm{KCl}$ for 48 hours. Extractions were analyzed for nitrate and ammonium at either 171 the Harvard Forest (Petersham, MA) or Marine Biological (Woods Hole, MA) Laboratories. Soil

$172 \mathrm{pH}$ and leaf litter dry mass were measured in 4 of the 6 experimental plots used in this study (A3, $173 \mathrm{~A} 4, \mathrm{~B} 2$, and $\mathrm{B} 4)$. Soil $\mathrm{pH}$ taken for the top $5 \mathrm{~cm}$ of mineral soil and was determined using a 174 Kelway soil $\mathrm{pH}$ and moisture meter on water-moistened soil (Kel Instruments Co., Inc. Wyckoff, 175 NJ, USA) for four samples per experimental plot. 178 assess the physiological changes of $H$. virginiana to experimental treatment. Here we include 179 only basic descriptions of the methods used. Detailed methods for each measurement can be 180 found in Appendix 1.

181 Growth - Due to the destructive nature of growth sampling methods, growth measurements were 182 taken on a separate set of $3 H$. virginiana individuals in each of the same six treatment plots as 
183 the individuals used for physiological measurements. Basal area of each individual was 184 calculated using the number and DBH of all stems $>1 \mathrm{~cm}$, given that many individuals had 185 multiple stems. Height of the tallest stem for each individual was measured using an $8 \mathrm{~m}$ 186 sighting pole, and crown area was approximated as a rectangle with dimensions equal to the 187 distance between the farthest leaves along the north-south and east-west azimuths.

Annual radial growth data were obtained from tree ring analysis of basal cross-section samples of the largest stem of each of 12 individuals (those for which annual growth rings could 190 be reliably cross-dated; 6 individuals in each treatment). Cross-sections were dried, sanded, and 191 ring widths cross-dated and quantified using a Velmex measuring system to the nearest 0.001 $192 \mathrm{~mm}$. For each individual, ring widths along two radii from pith to the outermost fully formed 193 ring were measured. Cross-dating among all measured series was verified using the program 194 COFECHA (Holmes 1983). Growth was calculated as basal area increment (BAI), which 195 represents the total basal area added to the tree over a given year and was calculated using the 196 width of the annual growth ring and the radius from the center of the stem to that growth ring. 197 BAI data were standardized to remove the influence of relative growth rates among individuals 198 and biological growth trends (Fritts 1976) using the dplR program in R statistical software 199 (Bunn 2008), and the BAI values for the two radii were averaged per individual. To assess the 200 response of BAI to canopy girdling, we also calculated the $\%$ change in BAI between the pre201 and post-girdling periods using the following equation:

$$
\% \text { Change }=\frac{\mu B A I_{\text {post }}-\mu B A I_{\text {pre }}}{\mu B A I_{\text {pre }}}
$$

202 where $\mu$ indicates the mean BAI. 
203 Specific Leaf Area - Specific Leaf Area (SLA) was measured for approximately 45 individual 204 leaves per experimental treatment. Leaf area was measured using a Li-Cor Li-3000 Leaf Area 205 Meter (Li-Cor Biosciences, NE, USA) on sun leaves lacking visual signs of damage haphazardly 206 chosen from the outer canopy of each $H$. virginiana individual. Leaves were then dried at $70{ }^{\circ} \mathrm{C}$ 207 for 72 hours to achieve constant mass. SLA was calculated as leaf area divided by dry mass.

208 Elemental and Isotopic Analysis - Approximately 4 leaves from each $H$. virginiana individual 209 were dried and ground using a ball-mill grinder. Leaf $\% \mathrm{C}$ and $\% \mathrm{~N}$ were determined using an 210 elemental analyzer (ECS 4010, Costech Analytical, Valencia, CA, USA) and $\delta^{15} \mathrm{~N}$ and $\delta^{13} \mathrm{C}$ were 211 measured using an isotope ratio mass spectrometer (Delta PlusXP, ThermoFinnigan, Bremen, 212 Germany) at Washington State University’s Stable Isotope Core Laboratory.

213 Foliar Pigments - Foliar chlorophyll, carotenoid, and anthocyanin concentrations were

214 determined using biochemical analyses on 4 cut leaf sections from each plant. Each leaf section 215 was ground, dissolved in acetone for chlorophyll and carotenoids and 1\% acidified methanol for 216 anthocyanins, and analyzed using a spectrophotometer (Vernier Software and Technology, OR, 217 USA) following protocols adapted from the Carnegie Spectranomics Protocol

218 (http://spectranomics.dge.carnegiescience.edu/Technical_Information). Pigment concentrations were 219 converted to be expressed on a leaf-area basis $\left(\mu \mathrm{g} / \mathrm{cm}^{2}\right)$ using the extract volume $(3 \mathrm{~mL})$ and the 220 product of the sample dry weight and specific leaf area.

221 Photosynthesis - Photosynthesis was measured in the lab on a single leaf from each individual

222 using an LI-6400 portable photosynthesis system (Li-Cor Biosciences, NE, USA). Leaves were 223 acclimated to a steady rate of photosynthesis for up to 40 mins, following which $\mathrm{CO}_{2}$ 224 assimilation rates (A) were measured at PAR levels varying from 0 to $1500 \mu \mathrm{mol} \mathrm{m}^{-2} \mathrm{~s}^{-1}$ to 225 produce light response curves (Appendix 1). Maximum photosynthetic capacity $\left(\mathrm{A}_{\max }\right)$ was 
226 determined as the highest photosynthetic rate along each leaf's light response curve. In addition

227 to plot-level light measurements taken using the hemispherical photographs described above, an

228 LAI-2000 Plant Canopy Analyzer (Li-Cor Biosciences, NE, USA) was used to take leaf-level

229 leaf area index (LAI) values above a small subset of leaves for which photosynthesis was

230 measured. Because LAI measurements for individuals leaves using the LAI-2000 required an

231 adjacent reference area of open sky, these measurements could only be taken in one plot (C2)

232 which contained a sufficient canopy gap. Following leaf-level LAI measurements, branches

233 containing each leaf were transported to the lab for photosynthesis measurements using the LI-

2346400 as described above.

235 Respiration - Respiration data were obtained using a custom-built plant gas exchange system 236 consisting of a sample cuvette heated by an F25-ME water bath (Julabo, PA, USA) and coupled 237 to an LI-6262 infrared gas analyzer (Li-Cor, NE, USA). Net $\mathrm{CO}_{2}$ efflux at temperatures from 5 $238{ }^{\circ} \mathrm{C}$ to $40{ }^{\circ} \mathrm{C}$ was measured by the infrared gas analyzer and applied to a modified Arrhenius 239 equation to model respiration sensitivity to temperature fluctuations (O'Sullivan et al. 2013).

240 Respiratory quotient data were obtained by dividing mean $\mathrm{CO}_{2}$ efflux at $25^{\circ} \mathrm{C}$ by $\mathrm{O}_{2}$ uptake data 241 obtained at $25^{\circ} \mathrm{C}$ using a SO-210 Fast Oxygen Sensor (Apogee Inst., UT, USA).

242 Statistical Analyses

Treatment effects for all physiological measurements were evaluated using a nested one244 way ANOVA with individual $H$. virginiana plants nested within each experimental plot, and 245 plots blocked by slope position (upper, mid, and lower). Where multiple leaves were measured 246 for each plant, leaf-level values were averaged and this mean value was used for plant-level data.

247 Growth data were analyzed using the average growth rate (BAI) of the individuals in both 248 treatment and control plots for the 4 years prior-to and following girdling implementation. 
249 Differences in soil $\mathrm{N}$ and growing-season temperature between control and oak-girdled plots

250 were assessed using a repeated-measures linear mixed effects model using plot as a random

251 factor. Because hemispherical photographs were not necessarily taken in the exact same location

252 from year to year, differences in growing-season canopy openness were assessed using a two-

253 way ANOVA with treatment and year as explanatory variables and plot as a random factor.

254 Statistical significance was assigned when $P<0.05$ and marginally significant when $P<0.1$. All

255 analyses were conducted in the base, nlme, and Hmisc packages of R statistical software, version

$256 \quad 3.2 .2(\mathrm{R}$ Core Team 2015).

257 Results

258 Environmental Changes Following Oak Girdling

Following oak girdling, canopy openness was $29 \%$ higher in the treated plots than control 260 plots on average $(P<0.001$; Figure 2$)$. Canopy openness did not vary significantly by year in

261 either control or oak-girdled plots, nor did the difference between control and oak-girdled plots

262 vary by year $(P>0.1$ for all). Understory air temperatures were not significantly different

263 between oak-girdled plots and control plots during the growing season (May-October; $P>0.1$ ).

264 Mean daily growing-season temperatures were $18.75^{\circ} \mathrm{C}$ and $19.10^{\circ} \mathrm{C}$ in control and oak-girdled 265 plots, respectively.

266 Prior to girdling, there were no significant differences in the availability of either nitrate

$267\left(\mathrm{NO}_{3}\right)$ or ammonium $\left(\mathrm{NH}_{4}\right)$ in the organic or mineral soil layers $(P>0.1$ for all, Figure 3$)$. In the

268 years following girdling, however, there was a $>1000 \%$ increase in available $\mathrm{NO}_{3}$ (averaged

269 across all post-girdling sample dates) in oak-girdled compared to control plots - an effect seen

270 primarily in the mineral soil layer (Figure 3b, d). Significant treatment effects for $\mathrm{NO}_{3}$ 
271 availability following girdling implementation occurred in both the organic $(P<0.01)$ and

272 mineral $(P<0.001)$ soil layers. Ammonium $\left(\mathrm{NH}_{4}\right)$ availability, however, did not differ

273 significantly by treatment post-girdling in either the organic or mineral soil layers $(P>0.1$ for

274 both soil layers, Figure 3a, c).

Soils were significantly less acidic in oak girdled plots vs. control plots $(P=0.024)$.

276 Mean $\mathrm{pH}$ for the upper $5 \mathrm{~cm}$ of mineral soil was $5.73( \pm 0.21)$ and $6.26( \pm 0.12)$ for control and

277 oak-girdled plots, respectively. However, leaf litter mass, soil bulk density, and soil N

278 concentrations did not differ significantly by treatment (data not shown).

279 Growth

Following the implementation of the girdling treatment in $2008, H$. virginiana shrubs in oak girdled plots showed an average $334 \%$ increase in annual basal area increment (BAI mm ${ }^{2} / \mathrm{yr}$ )

282 compared to years prior to girdling (Figure 4). This increase, averaged across years post-girdling,

283 was significantly greater than the percent difference in growth seen in control plots $(P<0.001)$.

284 No differences were found, however, in stem number, basal area, crown area, or height of $H$. 285 virginiana individuals between treatments $(P>0.1$ for all $)$.

286 Foliar SLA, \%N, \%C, $\delta^{15} N$, and Leaf Pigments

We did not detect any significant changes in SLA in response to girdling $(P>0.1$; Figure 5). Percent $\mathrm{N}$ was significantly higher for leaves in oak-girdled plots $(P=0.001)$, but $\% \mathrm{C}$ was 289 only marginally significantly different between experimental treatments $(P=0.059$; Figure 5).

290 The difference in $\% \mathrm{~N}$, however, was large enough to drive a significantly lower foliar C:N ratio 291 in oak girdled plots $\left(P=0.019\right.$; Figure 5). $\delta^{15} \mathrm{~N}$ values were significantly less negative for leaves 
292 in oak-girdled plots than those in control plots $(P<0.001)$, but no differences were found for $293 \delta^{13} \mathrm{C}(P>0.1)$.

H. virginiana leaves in oak-girdled plots had significantly higher total chlorophyll and bulk carotenoid content than did those in control plots $(P=0.004$ and 0.044 , respectively). No

296 significant differences, however, were found for the chlorophyll:carotenoid ratio across

297 treatments $(P>0.1)$. Anthocyanin levels between leaves of control and treatment plots were also 298 not significantly different $(P>0.1)$.

299 Photosynthesis

Maximum photosynthetic capacity $\left(A_{\max }\right)$ was marginally higher for $H$. virginiana plants

301 in oak girdled plots than in control plots when the leaves for each plant were pooled together for 302 statistical analysis $(P=0.089)$. Additionally, photosynthesis of individual leaves was strongly 303 positively correlated with light availability at the individual leaf level $\left(\mathrm{R}^{2}=0.826\right)$.

Dark Respiration, Respiratory Quotient, and Respiration Temperature Responses

306 leaves was not significantly different in oak-girdled than control plots $(P>0.1)$, nor was there a

307 difference in the respiratory quotient $\left(\mathrm{CO}_{2}\right.$ production to $\mathrm{O}_{2}$ uptake) between treatment groups $(P$

$308>0.1)$. There was, however, a significant treatment effect on the respiratory response to

309 temperature. Respiration of leaves from oak-girdled plots was marginally higher than from

310 control plots at $10{ }^{\circ} \mathrm{C}(P=0.064)$, but was significantly higher at $20{ }^{\circ} \mathrm{C}(P=0.0044)$, creating a

311 significant treatment by temperature interaction $(P=0.0205)$.

\section{Discussion}


Overall, the results of this study demonstrate that the multiple changes in the understory environment following canopy disturbance have varied physiological effects on the plants that 315 live there. Efforts combining a wide breadth of physiological metrics under a single study are 316 exceedingly rare, but may prove critical to understanding the multiple effects of future large317 scale forest disturbances (Chapin et al. 1987). The ability of this study to link light and nutrient 318 availability to changes in foliar chemistry, photosynthetic capacity, respiration, and growth 319 provides a uniquely comprehensive description of understory responses to canopy disturbance.

As expected, death of the dominant genus of canopy trees at this site significantly increased understory light availability - an effect that has persisted throughout the experiment's

322 duration. The peak in canopy openness in oak-girdled plots in 2010 corresponds to the delayed 323 mortality of many girdled trees 2-3 years after the girdling event in 2008 (designed to simulate 324 natural death by pathogens). This peak also corresponds to a relatively open-canopy year, as 325 demonstrated by high canopy openness values for both control and oak-girdled plots, which 326 resulted from leaf curling due to particularly dry conditions during that growing season. It is 327 important to note that measures of canopy openness were taken at a height of $1 \mathrm{~m}$, which is well 328 below the canopy height of $H$. virginiana $(5-7 \mathrm{~m})$. We observed significant increases in canopy 329 openness in oak-girdled plots below $H$. virginiana canopies despite the significantly higher 330 growth of $H$. virginiana in these plots. This suggests that differences in the openness of the forest 331 canopy, and subsequent increases in light availability to the forest floor, would be even greater 332 than we observed in the absence of the $H$. virginiana growth effect above our canopy openness 333 sampling height. represent an initial release and subsequent cessation of uptake of nitrate by oaks, which make up 
336 a large proportion of plant biomass at this site. Although not directly tested, soil temperature and

$337 \mathrm{CO}_{2}$ concentrations might have changed following canopy disturbance, making soil conditions

338 more favorable for bacteria to mineralize and nitrify soil N. Increased $\mathrm{N}$ mineralization rates may

339 also be partially due to the significantly lower $\mathrm{C}: \mathrm{N}$ of $H$. virginiana leaves in oak-girdled plots.

340 More neutral pH soils in oak-girdled plots are likely the result of reduced tannic acid from oak

341 leaf litter following girdling. Physiological changes of $H$. virginiana reported in this study

342 highlight the capacity of this species to respond to the multiple environmental changes following

343 canopy disturbance - responses that may have important impacts on the regenerating seedling

344 community and other understory plants among and below these shrubs.

experimental girdling led to dramatic increases in growth of $H$. virginiana shrubs under disturbed

canopies at this site. The $>300 \%$ increase in basal area increment indicates that $H$. virginiana

348 has a large capacity to respond to improved understory environmental conditions following

$\sim 600 \%$ growth increase previously observed for understory saplings of Betula lenta in response

352 been documented in response to canopy gaps in a variety of other understory species throughout

353 Northeastern forests (e.g. Sipe and Bazzaz 1994, Finzi and Canham 2000). Allometric equations

354 developed for $H$. virginiana (Wharton and Griffith 1993) suggest that the large BAI response

355 seen in girdled plots relates to an even larger difference in aboveground biomass growth

356 responses following canopy disturbance. While our data do not demonstrate differences in crown

357 area or height between control and oak-girdled plots, it is important to bear in mind that data for

358 these metrics were only available post-girdling. It is possible that crown area increased more 
359 over the four years post-girdling in the treatment plots than it did in the control plots, but that 360 control shrubs started out with larger crown areas initially. Considering this, basal area (BAI)

361 increases provide the most accurate indication of aboveground growth responses of $H$. virginiana 362 to large-scale canopy disturbance.

Significant changes in foliar $\mathrm{N}$ content and isotopic signature are likely the combined result of an increase in soil $\mathrm{N}$ availability and an increased demand for leaf $\mathrm{N}$ to drive photosynthesis in the high-light conditions of oak-girdled plots. The largest increase in available

366 inorganic $\mathrm{N}$ in oak-girdled plots was in the form of nitrate, suggesting that this $\mathrm{N}$ pool may play

367 an important role in $\mathrm{N}$ uptake in $H$. virginiana at this site. However, a small number of assays 368 showing extremely low nitrate reductase in $H$. virginiana at this site, as well as a study by Ross 369 et al. (2011), indicate that ammonium, not nitrate, is the preferred form of $\mathrm{N}$ for this species.

370 Foliar $\delta^{15} \mathrm{~N}$ responses may help to reconcile this discrepancy. Several studies have shown that 371 foliar $\delta^{15} \mathrm{~N}$ enrichment reflects increases in soil nitrification - the process by which ammonium is 372 transformed to nitrate (Garten 1993, Pardo et al. 2002). The significant enrichment of $\delta^{15} \mathrm{~N}$ found 373 here suggests higher nitrification rates in oak-girdled plots. Thus it is possible that decaying oak 374 tissue is actually increasing both nitrate and ammonium inputs into oak-girdled plots and that $H$. 375 virginiana is taking advantage of this increased ammonium availability, but that the increased 376 ammonium in oak-girdled plots is not reflected in our soil $\mathrm{N}$ data due to increased nitrification 377 rates converting the leftover ammonium to nitrate. Alternatively, the lack of large increases in 378 soil ammonium in girdled plots may simply reflect $H$. virginiana's preference for, and increased 379 uptake of, this form of inorganic N. Together, changes in soil $\mathrm{N}$, foliar $\% \mathrm{~N}$, and foliar $\delta^{15} \mathrm{~N}$ 380 suggest an increase in inorganic $\mathrm{N}$ uptake by $H$. virginiana following canopy disturbance. 
Responses of foliar chlorophyll and carotenoid concentrations provide the mechanistic

382 link between the increases in leaf $\% \mathrm{~N}$ and photosynthesis seen in this study. Because chlorophyll contains a large portion of the leaf's total $\mathrm{N}$ and serves as the initial light-gathering step in photosynthesis, increases in both foliar $\% \mathrm{~N}$ and light availability should lead to increased chlorophyll concentrations (Dillenburg et al. 1995, Sarijeva et al. 2007), as seen here. Carotenoid pigments in the leaf serve to protect the photosynthetic mechanism from high levels of irradiance (Sarijeva et al. 2007) - conditions experienced in oak-girdled plots in this experiment. Thus, the combined increases in chlorophyll and carotenoid content in the leaves of $H$. virginiana in oakgirdled plots suggest simultaneous increases in photosynthetic capacity and leaf protection against light-induced stress (Sarijeva et al. 2007).

The marginally significant increases in plant-level photosynthetic capacity seen here are likely due to large increases in light availability, coupled with increases in leaf pigment content, in oak girdled plots. The lack of strong statistical significance may be due to the high variability in light availability between individual leaves on a single plant or to the relatively late date in the growing season when these data were collected (though no signs of senescence were present at the time of sampling). Although this study focused exclusively on sun-lit leaves in both treatments, differences in the placement and orientation of individual leaves on the upper canopy of each shrub likely led to between-leaf variability in photosynthetic capacity that partially masked plant-level treatment effects. Indeed, for a subset of leaves measured in a single plot, 400 photosynthetic rates were found to be highly positively correlated with light levels measured 401 directly above the leaf $\left(\mathrm{R}^{2}=0.826\right)$. This conclusion is further supported by the large increase in 402 growth of $H$. virginiana individuals in treatment plots following girdling. Alternatively, increases 403 in growth of $H$. virginiana in oak-girdled plots may not be fueled by increases in photosynthetic 
404 rates at the leaf level, but by increases in total leaf area - a metric that was not directly assessed 405 in this study.

Even in the total absence of changes to photosynthetic capacity under disturbed canopies, 407 the significantly higher light levels should drive higher plant-level photosynthesis in oak-girdled 408 plots. Given the unexpected lack of a response in SLA (which has been seen elsewhere 409 (Kloeppel et al. 1993)) and crown diameter, higher light availability in girdled plots increasing 410 whole-plant photosynthetic rates is likely the most important driver of the growth responses we 411 observed. Finzi and Canham (2000) demonstrated that light plays the strongest role in 412 determining growth of saplings in canopy gaps of Northeastern forests, but that soil N may also 413 be an important factor. Given the significant changes in light availability, soil nitrate availability, 414 and foliar $\% \mathrm{~N}$ following oak-girdling, a combination of both light and $\mathrm{N}$ increases is likely 415 driving the growth responses seen here.

Increases in the response of respiration to temperature strongly suggest overall higher

417 metabolic activity of $H$. virginiana individuals in oak-girdled plots. The largest differences in 418 respiration between plots were seen at the $20^{\circ} \mathrm{C}$ reference temperature, which closely 419 corresponds to the mean daily temperatures experienced by $H$. virginiana during the growing 420 season at Black Rock Forest. Increases in respiration in oak-girdled plots at both reference 421 temperatures indicates acclimation in the overall respiratory capacity, as seen elsewhere (Atkin 422 and Tjoelker 2003, Atkin et al. 2005). It is important to note that many of the strongest responses, of both the understory 424 environment and of $H$. virginiana, documented here demonstrate what appear to be transient 425 temporal patterns (Figures $3 \& 4$ ). We consider our results primarily as responses averaged 426 across all post-girdling years, but both soil nitrate and growth data indicate dramatic decreases in 
427 girdling effects in the final post-girdling year in our dataset. Although we lack a sufficiently long

428 time series to confirm whether these responses were truly transient, these dynamics suggest that

429 the largest effects of $H$. virginiana on understory conditions likely occur in the initial 2-3 years

430 following canopy disturbance. This, in addition to sampling late in the growing season, may

431 explain why the physiological responses (i.e. photosynthesis and respiration) of H. virginiana did

432 not fully reflect the dramatic increases observed in this species' growth. Additionally, while it

433 has been shown that light is the primary driver of growth responses to canopy disturbance for

434 many understory species (Finzi and Canham 2000), the similarity in the temporal dynamics of

435 soil $\mathrm{N}$ availability and $H$. virginiana growth seen here indicates that a combination of both light

436 and soil $\mathrm{N}$ are important factors in how this species responds to the mortality of dominant canopy

437 trees.

The large increases in growth and physiological activity of $H$. virginiana in response to

439 canopy oak death indicate that this species may play an important role in determining the

440 environmental conditions for seedlings of regenerating canopy species as well as other

441 understory plants - especially in the critical period directly following canopy disturbance.

442 Greater aboveground biomass and belowground nutrient uptake by $H$. virginiana may alter or

443 mitigate the improved understory conditions for seedlings following canopy loss. Moreover, the

444 effects of understory shade on the physiology of seedlings following canopy disturbance has

445 been shown to have varying effects based on seedling species (Parker and Dey 2008). The shrub-

446 layer effect on seedlings may be especially important for communities dominated by $H$.

447 virginiana because of this species' resistance to herbivory by deer. Together, these results

448 indicate that, following potential loss of canopy oaks in eastern North America, regenerating 
449 seedling communities may become dominated by more shade-tolerant species where $H$.

450 virginiana is abundant and responding positively to canopy opening.

451 Conclusion

Together, the results reported here (increased $[\mathrm{N}]$, chlorophyll and carotenoid content,

453 respiration rates, and aboveground growth) suggest that $H$. virginiana plays an important role in

454 shaping understory conditions following large-scale canopy disturbance in northeastern

455 hardwood forests. As one of the most common understory shrubs in these forests, $H$. virginiana

456 inherently competes with seedlings and saplings of regenerating canopy species for light and soil

457 resources. While the increased light and $\mathrm{N}$ availability following canopy disturbance may favor

458 regenerating canopy juveniles, if $H$. virginiana is successful at competing for some portion of

459 these newly available resources in the understory, the responses of this species may help

460 determine regeneration rate and composition of the future canopy (Lorimer et al. 1994). Our

461 results strongly suggest that $H$. virginiana increases nitrogen uptake and aboveground growth.

462 For seedlings of regenerating canopy species, these effects of $H$. virginiana may play a role in

463 mitigating the increased resource availability in the understory due to canopy disturbance.

As human and climatic factors make northeastern hardwood forests prone to large-scale

465 tree pathogen outbreaks (Ayres and Lombardero 2000, Davidson et al. 2003, Fitchner et al.

466 2009), understanding how these forests will respond to such mortality events is increasingly

467 important. Despite never occupying the canopy layer, $H$. virginiana may serve a critical role in

468 shaping canopy composition and successional dynamics following disturbance due to its role as a

469 competitor in the regenerating understory. Given the high projected susceptibility of eastern

470 North American forests to tree pathogens (Lovett et al. 2006), the physiological responses of $H$. 
471 virginiana to large-scale canopy disturbance have important ecological implications not only for

472 this species but the entire community of many eastern hardwood forests.

\section{Acknowledgements}

474 The authors would like to thank G. Aitcheson, L. Akabas, N. Boelman, Y. Chen, C.

475 Gritsch, J. Green, D. Kennedy, and C. Quello, and H. T. Taylor for assistance with field and 476 laboratory analyses. We would also like to thank J. Brady, J. Caldwell, and M. Munson of the

477 Black Rock Forest Consortium staff for logistical support and maintenance of the experimental 478 site. 
479

480

481

482

483

484

485

486

487

488

489

490

491

492

493

494

495

496

497

498

499

\section{References}

Abrams, M.D., and Kubiske, M.E. 1990. Leaf structural characteristics of 31 hardwood and conifer tree species in central Wisconsin: Influence of light regime and shade-tolerance rank. For. Ecol. Manage. 31: 245-253.

Atkin, O.K., Bruhn, D., Hurry, V.M., and Tjoelker, M.G. 2005. The hot and the cold:

Unravelling the variable response of plant respiration to temperature. Funct. Plant Biol. 32(2): $87-105$.

Atkin, O.K., and Tjoelker, M.G. 2003. Thermal acclimation and the dynamic response of plant respiration to temperature. Trends Plant Sci. 8(7): 343-351.

Ayres, M.P., and Lombardero, M.J. 2000. Assessing the consequences of global change for forest disturbance from herbivores and patogens. Sci. Total Environ. 262: 263-286.

Barnard, E. 2007. Xylella fastidiosa and bacterial leaf scorch of oaks: suliminal, subtle, and suspect. In Proceedings of the 2nd National Oak Wilt Symposium. Austin, TX. pp. 1-5.

Boerner, R.E.J. 1985. Foliar nutrient dynamics, growth, and nutrient use efficiency of Hamamelis virginiana in three forest microsites. Botany 63: 1476-1481.

Bunn, A. 2008. A dendrochronology program library in R. Dendrochronologia 26: 115-124.

Chapin, F.S., Bloom, A.J., Field, C.B., and Waring, R.H. 1987. Plant responses to multiple environmental factors: Physiological ecology provides tools for studying how interacting environmental resources control plant growth. Bioscience 37(1): 49-57.

Davidson, J., Werres, S., Garbelotto, M., Hansen, E., and Rizzo, M. 2003. Sudden oak death and associated diseases caused by Phytophthora ramorum. Plant Heal. Prog.. 
500 Dillenburg, L.R., Sullivan, J.H., Teramura, A.H., and Sullivan, J.O.E.H. 1995. Expansion and 501 development of photosynthetic capacity and pigments in Liquidambar styraciflua (Hamamelidaceae) -Effects of Uv-B. Am. J. Bot. 82(7): 878-885.

503

504

505

506

507

508

509

510

Duckstein, S., and Stintzing, F. 2011. Investigation on the phenolic constituents in Hamamelis virginiana leaves by HPLC-DAD and LC-MS/MS. Anal. Bioanal. Chem. 401(2): 677-688.

Falxa-Raymond, N., Patterson, A.E., Schuster, W.S.F., and Griffin, K.L. 2012. Oak loss increases foliar nitrogen, $15 \mathrm{~N}$ and growth rates of Betula lenta in a northern temperate deciduous forest. Tree Physiol. 32: 1092-1101.

Fan, Z., Kabrick, J.M., Spetich, M.A., Shifley, S.R., and Jensen, R.G. 2008. Oak mortality associated with crown dieback and oak borer attack in the Ozark Highlands. For. Ecol. Manage. 255(7): 2297-2305.

Finzi, A.C., and Canham, C.D. 2000. Sapling growth in response to light and nitrogen availability in a southern New England forest. For. Ecol. Manage. 131(1-3): 153-165.

Fitchner, E., Lynch, S., and Rizzo, D. 2009. Survival, dispersal, and potential soil-mediated suppression of Phytophthora ramorum in a California Redwood-Tanoak forest. Phytopathology 99: 608-619.

Fritts, H. 1976. Tree Rings and Climate. In 1st edition. Academic Press, London.

Garten, C. 1993. Variation in foliar 15N abundance and the availability of soil nitrogen on Walker Branch watershed. Ecology 74(7): 2098-2113.

Gleason, H., and Cronquist, A. 1963. Manual of the Vascular Plants of Northeastern United States and Canada. Willard Grant Press, Boston, MA. 
521 Hicks, D., and Hustin, D. 1989. Response of Hamamelis virginiana L. to canopy gaps in a

522 Pennsylvania oak forest. Am. Midl. Nat. 121(1): 200-204.

523 Holmes, R.L. 1983. Computer-assisted quality control in tree-ring dating and measurement. Tree $524 \quad$ Ring Bull. 43(1): 69-78.

525 Jenkins, J.C., Aber, J.D., and Canham, C.D. 1999. Hemlock woolly adelgid impacts on 526 community structure and $\mathrm{N}$ cycling rates in eastern hemlock forests. Can. J. For. Res. 29: $527 \quad 630-645$.

528 Juzwik, J., Harrington, T.C., MacDonald, W.L., and Appel, D.N. 2008. The Origin of 529 Ceratocystis fagacearum, the Oak Wilt Fungus. Annu. Rev. Phytopathol. 46(1): 13-26.

530 Kabrick, J.M., Dey, D.C., Jensen, R.G., and Wallendorf, M. 2008. The role of environmental 531 factors in oak decline and mortality in the Ozark Highlands. For. Ecol. Manage. 255(5-6):

Kloeppel, B., Abrams, M.D., and Kubiske, M.E. 1993. Seasonal ecophysiology and leaf $1409-1417$.

Kruger, E.L., and Reich, P.B. 1997. Responses of hardwood regeneration to fire in mesic forest openings. Can. J. For. Res. 27(11): 1822-1831.

Levy-Varon, J.H., Schuster, W.S.F., and Griffin, K.L. 2012. The autotrophic contribution to soil 539 respiration in a northern temperate deciduous forest and its response to stand disturbance. Oecologia 169: 211-220.

541 Levy-Varon, J.H., Schuster, W.S.F., and Griffin, K.L. 2014. Rapid rebound of soil respiration 
542

543

544 545

546

547

548

549

550

551

552

553

554

555

556

557

558

559

560

561

562

following partial stand disturbance by tree girdling in a temperate deciduous forest.

Oecologia 174: 1415-1424.

Lorimer, C.G. 1993. Causes of the oak regeneration problem. In Oak regeneration: Serious problems, practical recommendations. USDA For Serv Gen Tech Rep, Asheville, NC. pp. 14-39.

Lorimer, C.G., Chapman, J.W., and Lambert, W.D. 1994. Tall understorey vegetation as a factor in the poor development of oak seedlings beneath mature stands. J. Ecol. 82(2): 227-237.

Lovett, G.M., Canham, C.D., Arthur, M. a., Weathers, K.C., and Fitzhugh, R.D. 2006. Forest ecosystem responses to exotic pests and pathogens in eastern North America. Bioscience 56(5): 395.

Lustenhouwer, M.N., Nicoll, L., and Ellison, A.M. 2012. Microclimatic effects of the loss of a foundation species from New England forests. Ecosphere 3: 1-16.

Marçais, B., and Bréda, N. 2006. Role of an opportunistic pathogen in the decline of stressed oak trees. J. Ecol. 94: 1214-1223.

McElrone, A.J., Jackson, S., and Habdas, P. 2008. Hydraulic disruption and passive migration by a bacterial pathogen in oak tree xylem. J. Exp. Bot. 59(10): 2649-2657.

Meentemeyer, R.K., Rank, N.E., Shoemaker, D.A., Oneal, C.B., Wickland, A.C., Frangioso, K.M., and Rizzo, D.M. 2008. Impact of sudden oak death on tree mortality in the Big Sur ecoregion of California. Biol. Invasions 10: 1243-1255.

NOAA. 2002. Monthly station normals of temperature, precipitation, and heating and cooling degree days. Asheville, NC. 
563 Noel, A. 1970. The girdled tree. Bot. Rev. 36(2): 162-195.

564 O’Sullivan, O.S., Weerasinghe, K.W.L.K., Evans, J.R., Egerton, J.J.G., Tjoelker, M.G., and 565 Atkin, O.K. 2013. High-resolution temperature responses of leaf respiration in snow gum 566 (Eucalyptus pauciflora) reveal high-temperature limits to respiratory function. Plant, Cell $567 \quad$ Environ. 36: 1268-1284.

568 Pardo, L.H., Hemond, H.F., Montoya, J.P., Fahey, T.J., and Siccama, T.G. 2002. N in forest soils 569 and foliage to high nitrate loss following clear-cutting. Can. J. For. Res. 32(7): 1126-1136.

570 Parker, W.C., and Dey, D.C. 2008. Influence of overstory density on ecophysiology of red oak 571 (Quercus rubra) and sugar maple (Acer saccharum) seedlings in central Ontario $572 \quad$ shelterwoods. Tree Physiol. 28(5): 797-804.

573 R Core Team. 2015. R: A language and environment for statistical computing. R Foundation for 574 Statistical Computing, Vienna, Austria. Available from http://www.r-project.org/.

575 Rizzo, D.M., Garbelotto, M., Davidson, J.M., Slaughter, G.W., and Koike, S.T. 2002.

576 Phytophthora ramorum as the cause of extensive mortality of Quercus spp. and Lithocarpus 577 densiflorus in California. Plant Dis. 86(12): 205-214.

578 Rooney, T.P. 2001. Deer impacts on forest ecosystems: a North American perspective. Forestry 579 74(3): 201-208.

Rooney, T.P., and Waller, D. 2003. Direct and indirect effects of white-tailed deer in forest ecosystems. For. Ecol. Manage. 181(1-2): 165-176.

Ross, K.A., Ehrenfeld, J.G., and Patel, M. V. 2011. The effects of nitrogen addition on the growth of two exotic and two native forest understory plants. Biol. Invasions 13(10): 2203- 
585

586

587

588

589

590

591

592

593

594

595

596

597

598

599

600

601

602

603

Sarijeva, G., Knapp, M., and Lichtenthaler, H.K. 2007. Differences in photosynthetic activity, chlorophyll and carotenoid levels, and in chlorophyll fluorescence parameters in green sun and shade leaves of Ginkgo and Fagus. J. Plant Physiol. 164(7): 950-955.

Schuster, W., Griffin, K., Roth, H., Turnbull, M., Whitehead, D., and Tissue, D. 2008. Changes in composition, structure and aboveground biomass over seventy-six years (1930-2006) in the Black Rock Forest, Hudson Highlands, southeastern New York State. Tree Physiol. 28: $537-549$.

Shifley, S.R., Fan, Z., Kabrick, J.M., and Jensen, R.G. 2006. Oak mortality risk factors and mortality estimation. For. Ecol. Manage. 229(1-3): 16-26.

Sipe, T.W., and Bazzaz, F.A. 1994. Gap partitioning among maples (Acer) in central New England: Shoot architecture and photosynthesis. Ecology 75(8): 2318-2332.

Tooley, P., and Kyde, K. 2003. Susceptibility of some eastern oak species to sudden oak death caused by Phytophthora ramorum. Phytopathology 93: S84.

Tooley, P., and Kyde, K. 2007. Susceptibility of some eastern forest species to Phytophthora ramorum. Plant Dis. 91: 435-438.

US Forest Service. 2007. Criteria and indicators for forest sustainability.

Wharton, E., and Griffith, D. 1993. Methods to estimate total forest biomass for extensive inventories: applications in the north-eastern US. Forest Service Research Paper NE-681. 


\section{Tables}

Table 1. Table of means ( \pm standard error) from control and oak-girdled plots for each of the physiological measurements used in this study. Measurements shown in bold exhibited significant differences between control and oak-girdled treatments.

\begin{tabular}{|c|c|c|c|c|}
\hline & "Measurement & Units & Control & Oak-girdled \\
\hline \multirow{9}{*}{ Foliar Traits } & SLA & $\mathrm{cm}^{2} / \mathrm{g}$ & $444.56(37.71)$ & $405.64(38.81)$ \\
\hline & Carbon & $\%$ & $42.11(0.70)$ & $44.60(1.04)$ \\
\hline & Nitrogen & $\%$ & $1.29(0.04)$ & $1.64(0.08)$ \\
\hline & $C: N$ & ratio & $35.08(1.48)$ & 29.38 (1.25) \\
\hline & $\delta^{15} \mathbf{N}$ & $\delta / \%$ & $-4.98(0.26)$ & $-2.43(0.33)$ \\
\hline & $\delta^{13} \mathrm{C}$ & $\delta / \%$ & $-32.27(0.14)$ & $-32.51(0.21)$ \\
\hline & Chlorophyll & $\mu \mathrm{g} / \mathrm{cm}^{2}$ & $13.90(1.46)$ & $20.22(2.37)$ \\
\hline & Carotenoid & $\mu \mathrm{g} / \mathrm{cm}^{2}$ & $1.20(0.03)$ & $1.64(0.17)$ \\
\hline & Anthocyanin & $\mu \mathrm{g} / \mathrm{cm}^{2}$ & $0.20(0.01)$ & $0.17(0.02)$ \\
\hline Photosynthesis & $\mathrm{A}_{\max }$ & $\mu \mathrm{mol} \mathrm{CO} / \mathrm{s}$ & $5.85(0.56)$ & $7.70(0.95)$ \\
\hline \multirow{4}{*}{ Respiration } & $\mathrm{R}_{\text {dark }}$ & $\mu \mathrm{mol} \mathrm{CO} / \mathrm{s}$ & $-0.63(0.08)$ & $-0.84(0.10)$ \\
\hline & $\mathbf{R}_{10}$ & $\mu \mathrm{mol} \mathrm{CO} / \mathrm{s}$ & $0.10(0.00)$ & $0.13(0.01)$ \\
\hline & $\mathbf{R}_{20}$ & $\mu \mathrm{mol} \mathrm{CO} / \mathrm{s}$ & $0.20(0.01)$ & $0.29(0.02)$ \\
\hline & $\begin{array}{c}\text { Respiratory } \\
\text { quotient }\end{array}$ & ratio & $0.97(0.06)$ & $0.88(0.07)$ \\
\hline \multirow{3}{*}{ Growth } & BAI* & $\%$ & $27.79(24.73)$ & $334.46(89.93)$ \\
\hline & Crown Area & $\mathrm{m}^{2}$ & $36.35(5.59)$ & $22.52(4.09)$ \\
\hline & Height & $\mathrm{m}$ & $6.15(0.47)$ & $5.81(0.35)$ \\
\hline
\end{tabular}

*Units of Basal Area Increment (BAI) are $\mathrm{mm}^{2} / \mathrm{yr}$, however, here we report the \% difference in mean pre- and post-girdling BAI for control and oak-girdled plots. 


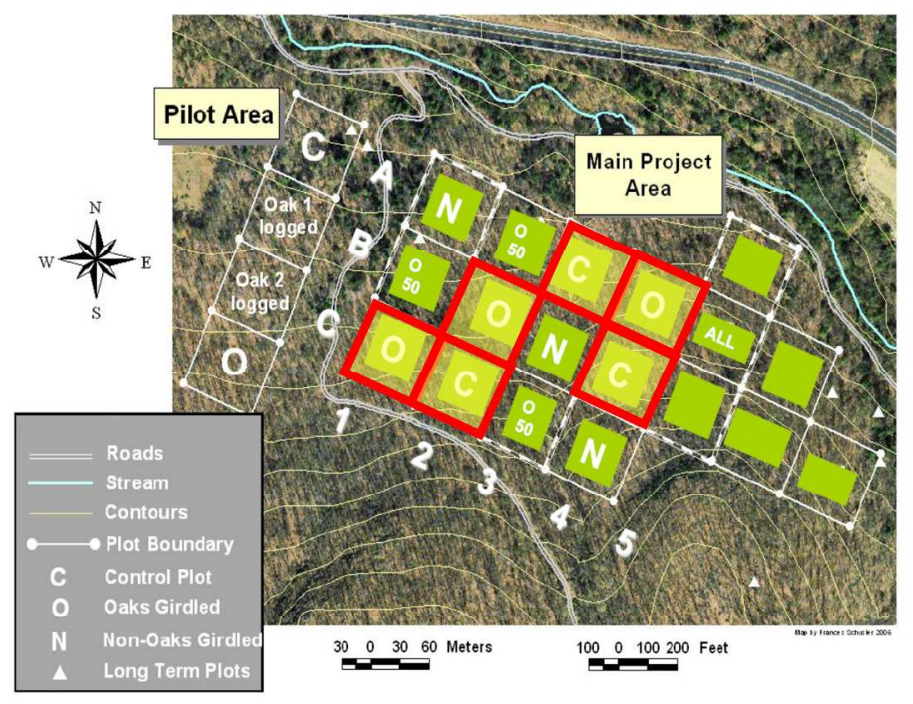

Design of the Future of Oak Forests Experiment at Black Rock Forest. Subplot rows are labelled with letters and subplot columns are labelled with numbers. Only highlighted subplots (C1, C2, B2, B4, A4, and A5) were used in this study.

$338 \times 190 \mathrm{~mm}(300 \times 300$ DPI $)$ 


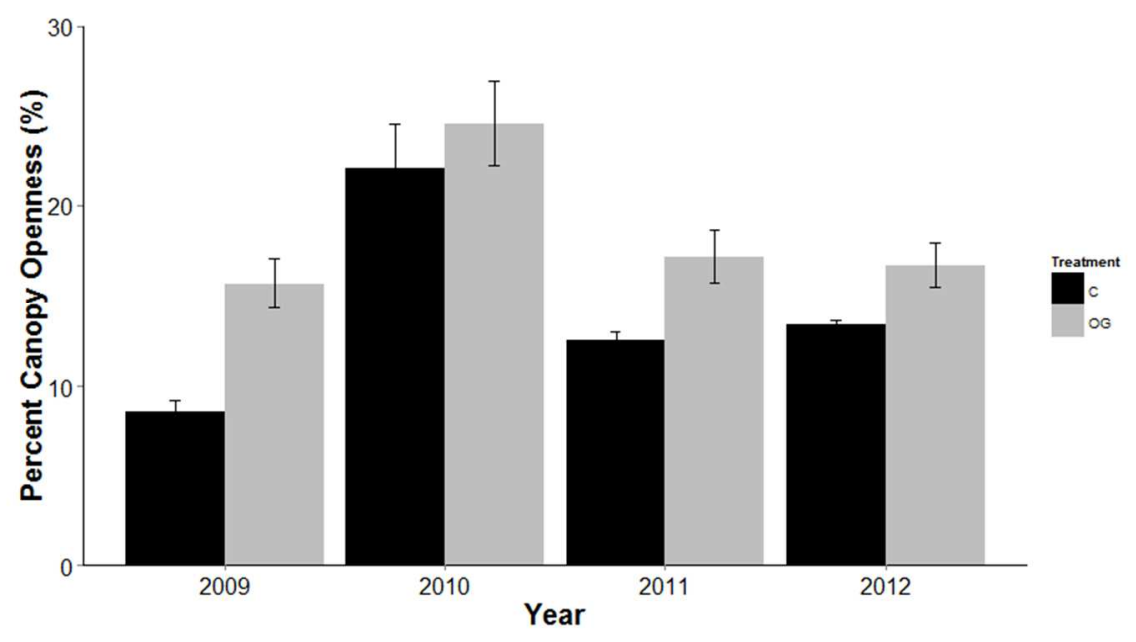

Mean ( \pm SE) percent canopy openness for control (grey) and oak-girdled (black) plots during the growing seasons of each of the four years directly following girdling implementation (2009 - 2012).

$338 \times 190 \mathrm{~mm}(300 \times 300 \mathrm{DPI})$ 


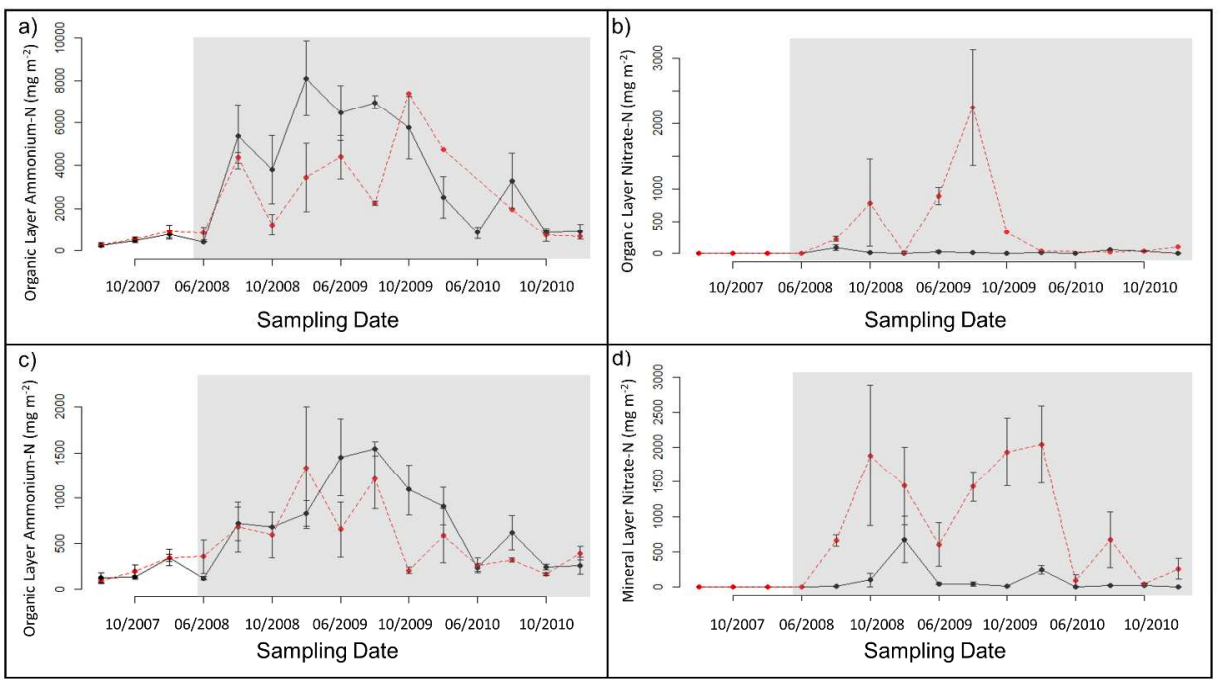

Soil inorganic nitrogen availability (mean \pm SE) for experimental plots prior to (unshaded region) and following (shaded region) girdling treatment implementation. Control plots are shown in solid black and oakgirdled plots are shown in dotted red. Organic soil layer a) ammonium and b) nitrate, and mineral soil layer c) ammonium and d) nitrate are shown.

$338 \times 190 \mathrm{~mm}(300 \times 300 \mathrm{DPI})$ 


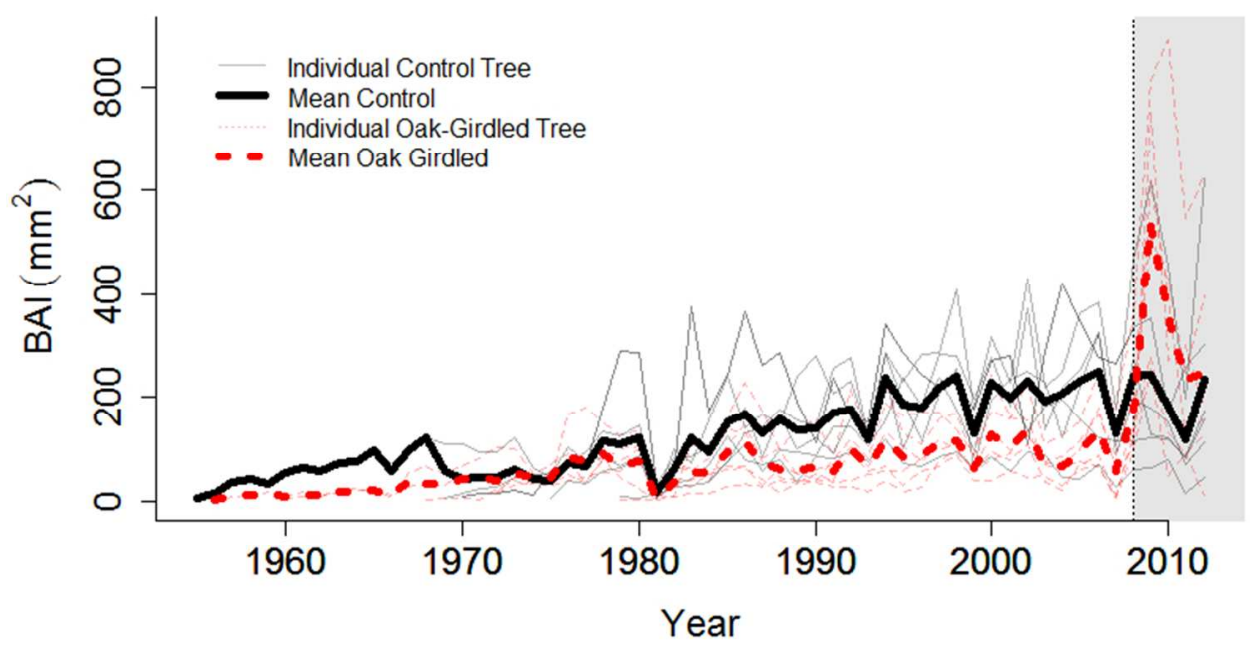

Basal Area Index (BAI mm2) of $\mathrm{H}$. virginiana individuals in control (thin grey dashed lines) and oak-girdled plots (thin pink dashed lines). Thick solid black and dashed red lines indicate the average BAI for control and oak-girdled individuals, respectively. The shaded portion represents the time period following girdling treatment implementation.

$291 \times 174 \mathrm{~mm}(72 \times 72$ DPI $)$ 
1 Taylor et al. Appendix 1. Full methods for physiological measurements

2 Specific Leaf Area - Specific Leaf Area (SLA) was measured for approximately 45 individual

3 leaves per experimental treatment. Leaf area was measured using a Li-Cor Li-3000 Leaf Area

4 Meter (Li-Cor Biosciences, NE, USA). Leaves were then dried at $70^{\circ} \mathrm{C}$ for 3 days to constant

5 mass. SLA was calculated as leaf area divided by dry mass.

6 Elemental and Isotopic Analysis - Three leaves from each tree sample were oven-dried at 60C

7 and ground up into a fine powder (Cianflone model 2601, Cianflone Scientific Instruments

8 Corporation, Pittsburgh, PA, USA). 1-4 mg of sample powder was weighed and placed into tin

9 capsules. Two replicates of samples were used: one complete set of samples were measured at

10 Columbia University for leaf tissue nutrient to obtain values for $\% \mathrm{C}$ and $\% \mathrm{~N}$, and another

11 complete set of samples were sent to Washington State University for leaf tissue stable isotope

12 analysis to obtain values for $\delta^{15} \mathrm{~N}$ and $\delta^{13} \mathrm{C}$. Nitrogen isotope signals are calculated as $\delta^{15} \mathrm{~N}$,

13 which represents ${ }^{15} \mathrm{~N}:{ }^{14} \mathrm{~N}$ ratio of leaf tissue relative to that of the background atmosphere $\mathrm{N}_{2}$.

14 Elemental analyzer (ECS 4010, Costech Analytical, Valencia, CA, USA) and isotope ratio mass

15 spectrometer (Delta PlusXP, ThermoFinnigan, Bremen, Germany) were used for isotopic

16 analysis.

17 Foliar Pigments -

18 Chlorophylls, carotenoids, and anthocyanins were extracted from a known area of leaf sample

19 taken from leaves of the same individuals collected for spectral analysis. Dry weight of the leaf

20 sample and its corresponding area was measured to determine specific leaf area. Four circular

21 punches of each leaf were taken for biochemical analysis and six for calculating specific leaf

22 area. For chlorophyll/carotenoid measurements, samples were frozen in liquid nitrogen and

23 ground quickly with magnesium carbonate and sand using a mortar and pestle. Leaf samples 
24 were collected in $3 \mathrm{~mL}$ of cold acetone and centrifuged for 2 minutes. The absorbance curves of

25 the supernatants were measured using a spectrophotometer (Vernier Software \& Technology,

26 Beaverton, OR, USA). When the absorbance of the extract solutions exceeded one, the solutions

27 were further diluted and absorbance was re-measured. The dilution factor was calculated from

28 the final volume of the solution over the initial volume of the solution $(3 \mathrm{~mL})$. For anthocyanin

29 measurement, the same protocol was repeated on separate punches from the same leaves but

30 because anthocyanins are unstable in acetone, extraction solvent was switched to $1 \%$ acidified

31 methanol. Equations were then applied to the respective absorbance curves to measure

32 chlorophyll, carotenoid, and anthocyanin concentrations (Lichtenthaler et al., 2001, Mancinelli

33 and Rabino 1984, Sims and Gamon 2002). Pigment concentrations were then converted to mass

34 per area $\left(\mu \mathrm{g} / \mathrm{cm}^{2}\right)$ by multiplying by the initial extract volume $(3 \mathrm{~mL})$ and dividing by the

35 product of sample dry weight and specific leaf area.

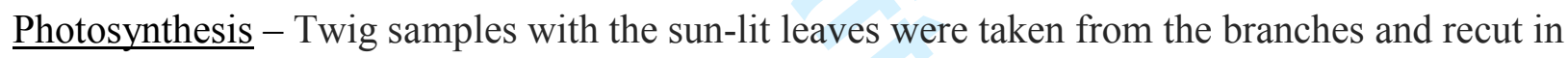

37 beakers with water. Individual leaves on each twig was placed in the leaf chamber of an infra-red gas analyzer (LI-6400 Portable Photosynthesis System, LI-COR). Three of these LI-COR gas analyzers were used with two systems providing 24 measurements of maximum $\mathrm{CO}_{2}$

40 assimilation rate $\left(\mathrm{P}_{\mathrm{Nmax}}\right)$ at decreasing PAR levels ranging from 1500 to $0 \mu \mathrm{m} \mathrm{m}^{-2} \mathrm{~s}^{-1}$, and the

41 third, an older model, providing only 20 measurements. Following the placement of a leaf within

42 a LI-COR system, the leaves were acclimated to a steady rate of photosynthesis under the

43 following settings: a flow rate of $500 \mu \mathrm{m}, \mathrm{a} \mathrm{CO}_{2}$ inflow of $400 \mathrm{ppm}$, a temperature of $25^{\circ} \mathrm{C}$, and a

44 photosynthetically active radiation (PAR) of $1500 \mu \mathrm{m} \mathrm{m}^{-2} \mathrm{~s}^{-1}$. Initial acclimation time varied

45 from approximately ten minutes to forty minutes. Upon acclimation, the light curve program was

46 run with $\mathrm{P}_{\mathrm{Nmax}}$ values recorded at the following levels of PAR $\left(\mu \mathrm{m} \mathrm{m}^{-2} \mathrm{~s}^{-1}\right): 1500,1000,500$, 
$47250,150,100,90,80,75,70,65,60,55,50,45,40,35,30,25,20,15,10,5,0$ with the older

48 model eliminating measurements taken at 75, 65, 55, and $5 \mu \mathrm{m}$. Once the program was complete,

49 the individual leaves were ejected from the leaf chamber and cut, taking extreme care to cut off

50 the petiole as well. Fresh weight (FW) in grams of each leaf was measured using a compact scale

51 (Fisher Science Education SLF303-US), while dry weight (DW) was estimated likewise after

52 drying at $70{ }^{\circ} \mathrm{C}$ for at least 72 hours. The leaf area index (LAI) of all investigated leaves were

53 taken using a leaf area meter (LI-3000A Portable Area Meter, LI-COR) in $\mathrm{cm}^{2}$.

54 Respiration - Branch samples were stored outside in sunlight. At the start of each trial, the leaf

55 sample was run through a leaf area meter to measure leaf area $\left(\mathrm{cm}^{2}\right)($ Licor $3000 \mathrm{C}$, Lincoln,

56 USA). Fresh mass was recorded for each leaf sample and then samples were placed into the

57 cuvette of the custom-built plant gas exchange system to measure respiration. Inside the cuvette,

58 a wire attached to an adaptor was pressed against the lower leaf surface to measure

59 temperature. The cuvette was covered with a dark cloth in order to stop photosynthesis and

60 promote respiration. Using a waterbath (Julabo F25-ME, Allentown, USA) the temperature

61 inside the cuvette was heated from $5^{\circ} \mathrm{C}$ to $40{ }^{\circ} \mathrm{C}$ at a rate of $1{ }^{\circ} \mathrm{C}$ per minute. $\mathrm{Net}^{\mathrm{CO}_{2}}$ release

62 from the leaf was measured in $\mu \mathrm{mol} \mathrm{CO} \mathrm{Cm}^{-2} \mathrm{~s}^{-1}$ using an infrared gas analyzer (Licor 6262,

63 Lincoln, USA). This process was repeated for each of the eighteen samples. After measuring

64 respiration, leaf samples were placed in coin envelopes, labeled, and then dried in an oven at 70

$65{ }^{\circ} \mathrm{C}$ for two days. Dry weight values were recorded.

66 A modified Arrhenius equation was used to model respiration between $5-40{ }^{\circ} \mathrm{C}$ (Eq.1)

67 (O’Sullivan et al. 2013). Equation 1 was adapted from O'Sullivan et al. is one of seven discussed 
68 in the paper for modeling respiratory response curves and was found to maximize the $r^{2}$ value of

69 the relationship between the measured and modeled data (2013).

$$
R=R_{20} e^{\frac{E_{0}\left(\frac{1}{T_{20}}-\frac{1}{T_{a}}\right)}{e^{2}}}
$$

(Equation 1)

71 In this equation, $\mathrm{E}_{0}$ represents a parameter related to the energy of activation and it defines the

72 shape of the response curve. Because of our chosen reference temperature of $20{ }^{\circ} \mathrm{C}, \mathrm{R}_{20}$ is

73 respiration at that temperature and $\mathrm{T}_{20}$ is simply $20^{\circ} \mathrm{C}$. Finally $\mathrm{g}$ is the universal gas constant

$74 \quad\left(8.314 \mathrm{~J} \mathrm{~mol}^{-1} \mathrm{~K}^{-1}\right)$ and $\mathrm{T}_{\mathrm{a}}$ is the ambient temperature.

75 Using the solver function in Excel, the square of the standard deviations was minimized by

76 manipulating $\mathrm{E}_{0}$ and $\mathrm{R}_{20}$. From the results of the temperature response fit curve, values for $\mathrm{E}_{0}$,

$77 \mathrm{R}_{10}$, and $\mathrm{R}_{20}$ were compiled for each of the eighteen samples.

78 Growth - Within each of the six plots (A3, A4, B2, B4, C1, and C2), we selected three $H$.

79 virginiana individuals for a total of 18 trees sampled. For each individual, we counted and 80 measured diameter at breast height $(\mathrm{DBH})$ for all stems $>1 \mathrm{~cm}$. We used an eight-meter sighting 81 pole to measure the height of the tallest stem. We approximated crown area by measuring the

82 distance between the farthest leaves or branches along the north-south azimuth and again along 83 the east-west azimuth, ensuring that the two measurement axes crossed at the center of the 84 crown. Crown area was then approximated as a rectangle whose area was equal to the product of 85 those two measures. Following these measurements, we destructively sampled the $H$. virginiana 86 individuals and collected a cross-section near the base of the largest stem. Basal cross-sections were processed following standard dendrochronological procedures

88 (Stokes and Smiley 1968). The 18 cross-sections were dried and sanded with progressively finer 
89 sandpaper until ring boundaries were easily distinguishable. H. virginiana is a diffuse porous to

90 slightly semi-ring-porous species (Schweingruber 2011) with occasional micro rings, and

91 therefore requires very fine (>1000 grit) sanding. The annual rings were visually cross-dated and

92 then measured with a Velmex measuring system to the nearest $0.001 \mathrm{~mm}$. Two radii, from the

93 pith to outermost fully-formed ring, were measured for each cross-section. Only 12 of the 18

94 total cross-sections, including six from oak girdled plots and six from control plots, could be

95 measured and analyzed. Visual cross-dating was verified statistically with the software program

96 COFECHA (Holmes, 1983) using a correlation analysis window of 25 years lagged by 10 years.

97 The raw ring-width measurements were converted to basal area increment (BAI) using the

98 “inside-out" calculation in program dplR (Bunn, 2008) in the R software environment. The BAI

99 for both radii were averaged per individual shrub. The years directly following the girdling

100 treatment, 2009 to 2012, were studied visually and quantitatively to identify potential growth

101 releases in the BAI series. We quantified any changes in growth by determining the percent

102 change in BAI from an average of 2004-2007 (no girdling effect) to 2009-2012 (full girdling

103 effect).

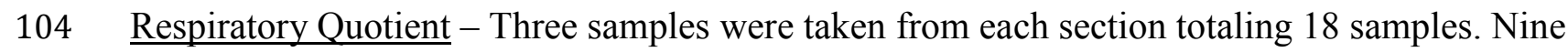

105 samples were taken from girdled plots and another nine samples were obtained from control

106 plots. Each sample was composed of 11-35 leaves. The samples have been weighted and leaf

107 area measured; both were reported as the cumulated leaf area and cumulated weight of the leaves

108 of the entire sample.

109 Leaves were placed into a glass container positioned in a water bath maintained at $25{ }^{\circ} \mathrm{C}$,

110 after a 10 minute acclimation in the open container. The carbon dioxide and oxygen

111 concentrations were monitored thanks to adapted sensors (IRGA Li 840 infrared gas analyzer, 
112 LiCor, Lincoln NE; and SO-210 Fast Oxygen Sensor, Apogee Inst. Logan Utah). Trials were run

113 until $\mathrm{CO}_{2}$ reached a minimum of $3000 \mathrm{ppm}$ allowing for changes in oxygen gas levels to be

114 significant enough to enable interpretation.

115 At the end of the experiment, the leaves were dried to a constant mass in a $70{ }^{\circ} \mathrm{C}$

116 convection drying oven. Once dry, the leaf material was reweighed. Leaf mass per area (SLA,

$117 \mathrm{~cm}^{2} \mathrm{~g}^{-1}$ ), and leaf dry matter content (DMC, dry mass per unit wet mass) was determined from

118 the total fresh mass, total dry mass, total leaf area (Patterson 2012).

119 For each experiment we calculated the mean rate of increase of carbon dioxide

120 concentration and the mean rate of decrease of the oxygen concentration by a linear interpolation.

121 The data points of the first minutes (from one to four minutes depending of the sample) were

122 discarded in order to account for the stabilization and homogenization of the gas composition in

123 the container. The respiratory quotient was obtained by dividing the mean rate of increase of

124 carbon dioxide concentration by the mean rate of decrease of the oxygen concentration. 
Supplementary data: Growth and physiology of a dominant understory shrub, Hamamelis virginiana, following canopy disturbance in a temperate hardwood forest

\section{Contents: Table S1, Fig. S1}

Table S1. Table of ANOVA results for tests of environmental and physiological data

\begin{tabular}{|c|c|c|c|}
\hline Theasurement & $\begin{array}{c}\text { Residual Degrees } \\
\text { of Freedom }\end{array}$ & F-statistic & P-value \\
\hline SLA & 84 & 0.5044 & .4796 \\
\hline Foliar $\% \mathrm{C}$ & 13 & 4.2628 & .0595 \\
\hline Foliar $\% \mathrm{~N}$ & 13 & 17.2942 & .001123 \\
\hline Foliar C:N & 13 & 7.1246 & .01929 \\
\hline Foliar $\delta^{15} \mathrm{~N}$ & 13 & 40.0591 & .0000262 \\
\hline Foliar $\delta^{13} \mathrm{C}$ & 13 & 0.7878 & .3909 \\
\hline Chlorophyll & 12 & 12.2476 & .004385 \\
\hline Carotenoid & 12 & 5.0555 & .04412 \\
\hline Anthocyanin & 12 & 2.8061 & .11975 \\
\hline $\mathrm{A}_{\max }$ & 12 & 3.4209 & .08915 \\
\hline $\mathrm{R}_{\text {dark }}$ & 12 & 2.2025 & .1636 \\
\hline $\mathrm{R}_{10}$ & 11 & 4.2259 & .06434 \\
\hline $\mathrm{R}_{20}$ & 11 & 12.7651 & .004373 \\
\hline Respiratory Quotient & 12 & 1.1136 & .3121 \\
\hline BAI & 6 & 90.665 & .0000765 \\
\hline Crown Area & 12 & 0.0729 & .7917 \\
\hline Height & 12 & .2632 & .6173 \\
\hline $\begin{array}{c}\text { Canopy Openness } \\
\text { (Treatment) }\end{array}$ & 122 & 13.332 & .000385 \\
\hline $\begin{array}{l}\text { Canopy Openness } \\
\text { (Treatment x Year) }\end{array}$ & 122 & 0.735 & .392875 \\
\hline Leaf Litter dry weight & 12 & 1.1142 & .3120 \\
\hline Soil pH & 12 & 6.6751 & .02394 \\
\hline Soil Bulk Density & 28 & 0.2469 & .62318 \\
\hline Soil Moisture & 22 & 2.5126 & .127208 \\
\hline
\end{tabular}


Figure S1. Plot of Basal Area Increment (BAI) for only the 4 years prior-to and following girdling treatment implementation.

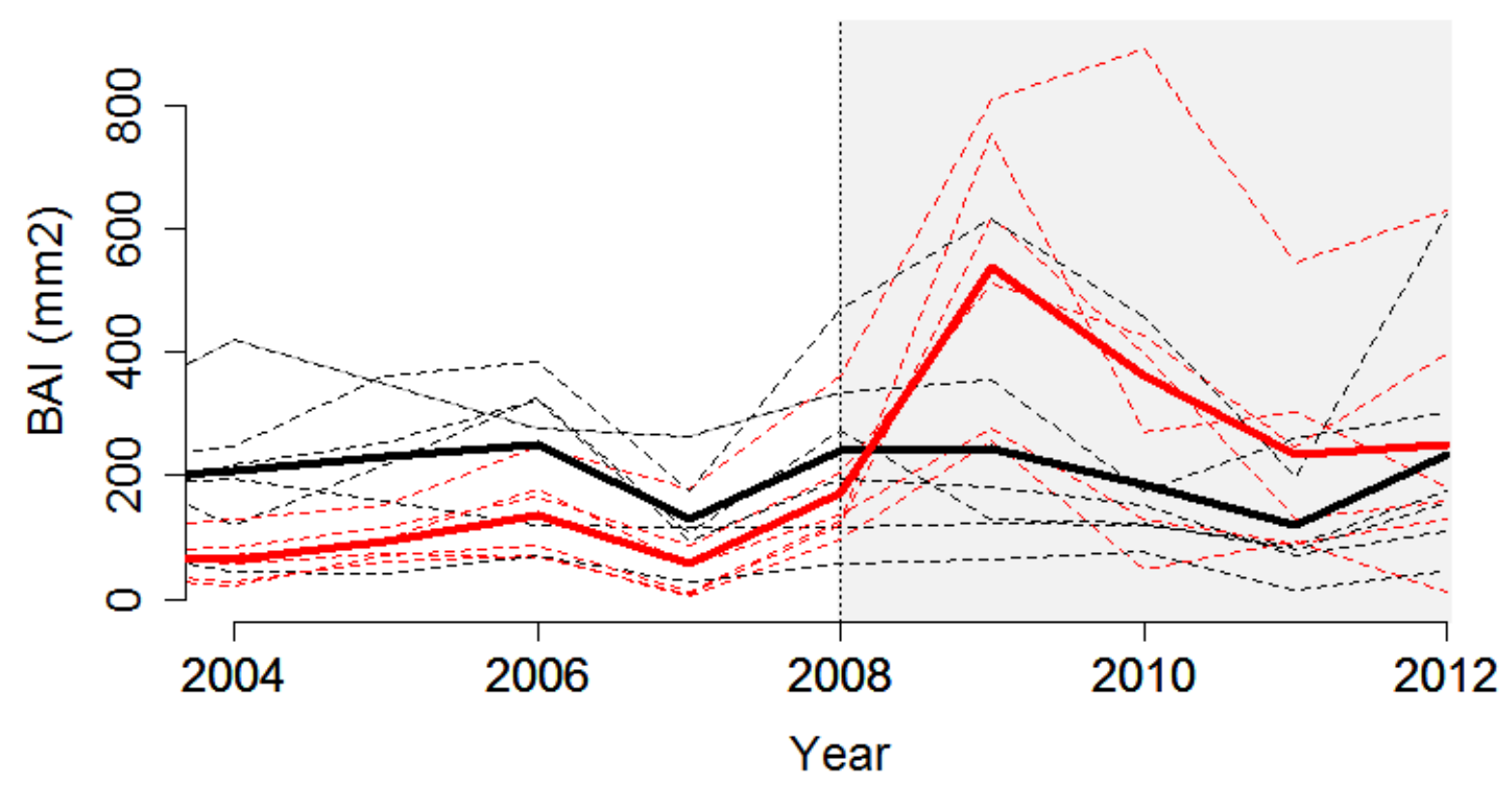

